\title{
Biological contaminants in insects as food and feed
}

\author{
D. Vandeweyer ${ }^{1,2 \#}$, J. De Smet ${ }^{1,2 \#}$, N. Van Looveren ${ }^{1,2}$ and L. Van Campenhout ${ }^{1,2^{*}}$ \\ ${ }^{1}$ KU Leuven, Department of Microbial and Molecular Systems (M2S), Lab4Food, Geel Campus, Kleinhoefstraat 4, 2440 Geel, \\ Belgium; ${ }^{2}$ KU Leuven, Leuven Food Science and Nutrition Research Centre (LFoRCe), Kasteelpark Arenberg 20, Box 2463, \\ 3001 Leuven, Belgium; leen.vancampenhout@kuleuven.be; ${ }^{\#}$ These authors contributed equally
}

Received: 23 June 2020 / Accepted: 9 October 2020

(c) 2021 Wageningen Academic Publishers

OPEN ACCESS @(1) @ (0) REVIEW ARTICLE

\begin{abstract}
During the last decade, edible insects have successfully taken a meaningful position in the feed and food chain. To expand this position, product safety continuously needs to be warranted. This review focuses on the current knowledge and the future challenges on the prevalence of human foodborne pathogens in edible insects. The top three of the bacterial pathogens associated with insects for food are Staphylococcus aureus, pathogenic Clostridium spp. and pathogenic species of the Bacillus cereus group. Less is known about other types of biological contaminants, the fungi, viruses, protozoa and prions. For insects for feed, even less reports on pathogens are available so far, although the microbiota of Hermetia illucens is increasingly being studied in the latest years. In addition to the evaluation of endogenous microorganisms in insects, an overview is given of inoculation experiments to study the fate of specific food pathogens during rearing. Future challenges that are identified mainly relate to the fact that risk assessments directed to specific insect species are needed. Also, more research data are needed on the microbiological quality of substrates and residue, in connection with decontamination treatments. The house flora of rearing facilities has not been investigated before. The insect supply chain can generate insights in the microbiological quality of the integral chain by implementing exhaustive sampling plans and by applying predictive microbiology. Additionally, microbiological methods used in research and quality control require standardisation. Rather unexplored so far is the unculturable fraction of the insect microbial community and its importance in food safety. Last but not least, the most important microbiological challenge may well be situated in the further development of the sector: upscaling in terms of capacity and number of companies will increase the complexity of the sector. That will have implications for monitoring and control of biological contaminants.
\end{abstract}

Keywords: edible insects, microbiological pathogens, microbiological safety

\section{Introduction}

In addition to physical and chemical safety, feed and food also have to comply with biological safety. The legal microbiological criteria applicable for the feed and food industry rely on culture-dependent methods, in which a fresh sample is diluted or alternatively resuscitated, and then plated and incubated to determine colony counts, or incubated to observe the absence or presence of a food pathogen, respectively. Hence, depending on the biological contaminant, safety involves either its presence to be below a specific level or its complete absence in a predefined quantity of the matrix (De Loy-Hendrickx et al., 2018). Biological contaminants (hazards) encompass pathogenic strains of micro-organisms (i.e. bacteria, viruses and fungi, which contain both moulds and yeasts), and of parasites (i.e. protozoa and worms), as well as the toxic substances (chemicals) they produce, i.e. bacterial toxins, such as for instance cereulide, histamine, botulin, or mycotoxins (WHO, 1995; Zwietering et al., 2016).

In the last decade, and as shown in this review, increasingly more reports appear that describe the complete microbiome or subgroups of insect species reared for animal or human food, focusing on the rearing stage and/or post-harvest practices. In some of these studies, special attention is paid to - mostly bacterial - pathogens that can cause zoonoses. Conclusions with respect to microbiological 
safety are often difficult to draw. A first reason for this is that legislation on microbiological criteria for insects as feed or food, to be used as a reference for what can be considered as safe, is limited, as also concluded by Garofalo et al. (2019). Biological safety is not yet well established for insects and therefore legislation is not extensive. The extrapolation of microbiological criteria from other food types (e.g. included in Regulation (EC) No 2073/2005 on microbiological criteria for foodstuffs; EC, 2005) to insects is hardly relevant, since pathogens show a different growth pattern and physiological behaviour, such as sporulation or spore germination, in diverse foods with concomitant intrinsic and extrinsic properties (Jay et al., 2005). Secondly, for some bacterial contaminants criteria exist for insects, but results reported in literature do not always involve the required amount of samples, or the results were not obtained using the methods described in the criteria.

The aim of this review is twofold. In a first part, we present an update of reviews and studies available, describing certain biological contaminants in insects for food and feed. In this review, we consider the possible occurrence of pathogenic bacteria, fungi and viruses, prions and protozoa, but we do not focus on the presence of toxic compounds produced by micro-organisms. In this first part, we make a further distinction: we first describe pathogens in insect species produced for food purposes only or for both food and feed, and secondly we describe pathogens in insects to be (generally) used in feed only. The reason for this structure is that there is a clear distinction in the amount of data available in the two domains. For insects for food or both food and feed, several studies are acquirable, and this work even has been summarised in several reviews. Hence, we will build on the most recent reviews, compare them and add reports that appeared after them, to come to the main state of the art. In contrast, for insects only used for feed, little data are available. Therefore, we provide an overview of original data, collected through searches in PubMed, Google Scholar and Web of Science, by using the search terms 'housefly,' 'Musca domestica,' 'black soldier fly', or 'Hermetia illucens', each combined with 'microbiota' or 'microbiome.' Only papers related to mass rearing of the insects were considered. In the second part, this review also aims at deeply discussing the future challenges in both the research on biological contaminants as well as the practical implementation of measurements to warrant biological safety in the context of the rapidly evolving insect rearing and processing sectors.

\section{Biological risks associated with insects to be used in food or in both food and feed}

In 2019, four literature reviews were published online that discuss studies performed so far on the microbiological quality and safety of mass reared insects for human food purposes. The reviews have in common that none of them explicitly describes biological risks for producing and processing insects into animal feed. All of them consider the industrial scale production of insects, and three of them also include insects that are wild-harvested at large scale (Table 1). While all reviews do not only cover the rearing phase but also post-harvest processing, they differ somewhat with respect to the mentioned technologies (Table 1). Finally, all reviews discuss results obtained by both culture-independent microbiological analyses (plates counts, presence absence tests), as well as by the mostly used culture-independent approach for microbial community assessment, metagenetics. Metagenetics is based on a polymerase chain reaction (PCR) to amplify and then sequence certain phylum-specific genes, typically the $16 \mathrm{~S}$ ribosomal RNA gene for bacteria and 18S rRNA gene for fungi, from all DNA extracted from a whole microbial community (Martin et al., 2018). Below, we shortly describe the specificities of each review and then consolidate the main findings.

Murefu et al. (2019) reviewed the food safety hazards of both reared and wild-harvested edible insects. The study revealed the lead of Africa in studying food safety of insects until 2016, yet on wild-harvested insects (Figure 1). Later, the majority of studies reporting food safety of edible insects were European, investigating other, reared species. It was concluded that the harvesting type (wild or reared) strongly affects the food safety of the insect. Regarding biological risks, the bacteria Bacillus (cereus group), Clostridium and Staphylococcus as well as the fungi Aspergillus and Penicillium were regularly mentioned for the five main edible insect species considered in this study (Table 2), as well as for several additional African species.

In the review by Garofalo et al. (2019), data originated from over 32 species (7 orders) of both fresh and processed insects, either harvested in the wild or (industrially) reared (Figure 1). Furthermore, also microbiological data from insect-based products were included in the review. Up till 2015, most data were obtained from wild-harvested African insect species, while as from 2016, associated with the renewed novel food regulation (Regulation (EU) No. 2015/2283; EC, 2015), a drastic increase in scientific studies on edible insects reared in Europe was observed (Figure 1). Consequently, the most studied insects for human food nowadays are the yellow mealworm (Tenebrio molitor), the lesser mealworm (Alphitobius diaperinus), the house cricket (Acheta domesticus), the tropical house cricket (Gryllodes sigillatus) and the migratory locust (Locusta migratoria). With an extensive metadata collection, Garofalo et al. (2019) were able to assess and discuss both food hygiene and food safety of edible insects. Additionally, the data provided insight into the microbial profiles associated with different insect species, to evaluate their dynamics during rearing and the effect of commonly applied treatments on those microbial profiles. Pathogenic microorganisms reported in 
Table 1. Comparison of the four review publications on the microbiological safety of insects for food published online in 2019.

\begin{tabular}{|c|c|c|c|c|}
\hline \multirow[t]{2}{*}{ Review characteristics } & \multicolumn{4}{|l|}{ Reviews } \\
\hline & Murefu et al. (2019) & Garofalo et al. (2019) & Cappelli et al. (2020) & Kooh et al. (2019) \\
\hline Online publication date & 6 March 2019 & 25 July 2019 & 6 September 2019 & 14 October 2019 \\
\hline Time span covered ${ }^{1}$ & 1993-2019 & $2000-2019$ & $2016-2019$ & $1994-2019$ \\
\hline $\begin{array}{l}\text { Systematic or narrative } \\
\text { review }^{2}\end{array}$ & systematic & systematic & systematic & narrative \\
\hline $\begin{array}{l}\text { Including wild-harvested } \\
\text { insects? }\end{array}$ & yes & yes & no & yes \\
\hline $\begin{array}{l}\text { Post-harvest treatments } \\
\text { described with respect to } \\
\text { effect on microbiological } \\
\text { quality }\end{array}$ & $\begin{array}{l}\text { blanching } \\
\text { (par)boiling/cooking } \\
\text { canning } \\
\text { chilling } \\
\text { degutting } \\
\text { drying }^{3} \\
\text { fermenting } \\
\text { freezing } \\
\text { frying } \\
\text { milling/grinding/grounding/ } \\
\text { pulverising } \\
\text { packing (vacuum or not) } \\
\text { plucking } \\
\text { rinsing/washing } \\
\text { roasting } \\
\text { salting } \\
\text { smoking } \\
\text { sterilising }\end{array}$ & $\begin{array}{l}\text { blanching } \\
\text { boiling/cooking } \\
\text { chilling } \\
\text { degutting } \\
\text { drying }^{3} \\
\text { extruding } \\
\text { fermenting } \\
\text { (deep-)frying } \\
\text { marinating } \\
\text { milling/crushing } \\
\text { plucking } \\
\text { rinsing/washing } \\
\text { roasting } \\
\text { salting } \\
\text { smoking } \\
\text { spicing/condimenting } \\
\text { starving } \\
\text { sterilising }\end{array}$ & $\begin{array}{l}\text { blanching } \\
\text { boiling/(vacuum) cooking } \\
\text { chilling } \\
\text { cold atmospheric pressure } \\
\text { plasma } \\
\text { crushing/grinding } \\
\text { drying }^{3} \\
\text { enzymatic hydrolysis }_{\text {fermenting }} \\
\text { fractionating } \\
\text { freezing } \\
\text { frying } \\
\text { in vitro digestion } \\
\text { marinating } \\
\text { pH change } \\
\text { pureeing } \\
\text { rinsing/washing } \\
\text { roasting } \\
\text { smoking } \\
\text { starving/fasting } \\
\text { sterilising }\end{array}$ & $\begin{array}{l}\text { boiling/cooking } \\
\text { grinding } \\
\text { drying }^{3} \\
\text { freezing } \\
\text { frying } \\
\text { high hydrostatic pressure } \\
\text { packing } \\
\text { rinsing } \\
\text { roasting } \\
\text { starving/fasting }\end{array}$ \\
\hline
\end{tabular}

the aforementioned most important insect species for food are listed in Table 2. The list contains both spore-forming and non-spore-forming bacteria, as well as mycotoxinproducing fungi. From the data compiled by Garofalo et al. (2019), it can be concluded that the bacterial genera Bacillus (including the B. cereus group, as discussed further below), Clostridium (including Clostridium perfringens), and Staphylococcus (including Staphylococcus aureus) are to be considered as the most relevant risks regarding food safety of edible insects. The genera Cronobacter (including C. sakazakii), Pseudomonas (including Pseudomonas aeruginosa), Vibrio, Campylobacter, Salmonella and Listeria (including Listeria monocytogenes) were concluded to pose a lower risk. More recently, presumptive Cronobacter spp. were detected sporadically in freeze-dried lesser mealworms and in house cricket meal (Greenhalgh and Amund, 2019), but also here, safety risks were concluded to be low. Regarding mycotoxin-producing fungi, Aspergillus spp. and Penicillium spp. were found to involve the highest risks.

Cappelli et al. (2020) provided a chemical and microbiological risk assessment applied on the insect families Tenebrionidae (darkling beetles, including T. molitor and $A$. diaperinus) and Gryllidae (crickets, including A. domesticus and G. sigillatus). Regarding the microbiological risks, human foodborne pathogens that were reported per insect species are again included in Table 2. The genera Bacillus, Clostridium and Staphylococcus were mentioned most often and also this study concluded that Salmonella spp. and L. monocytogenes are low-level 


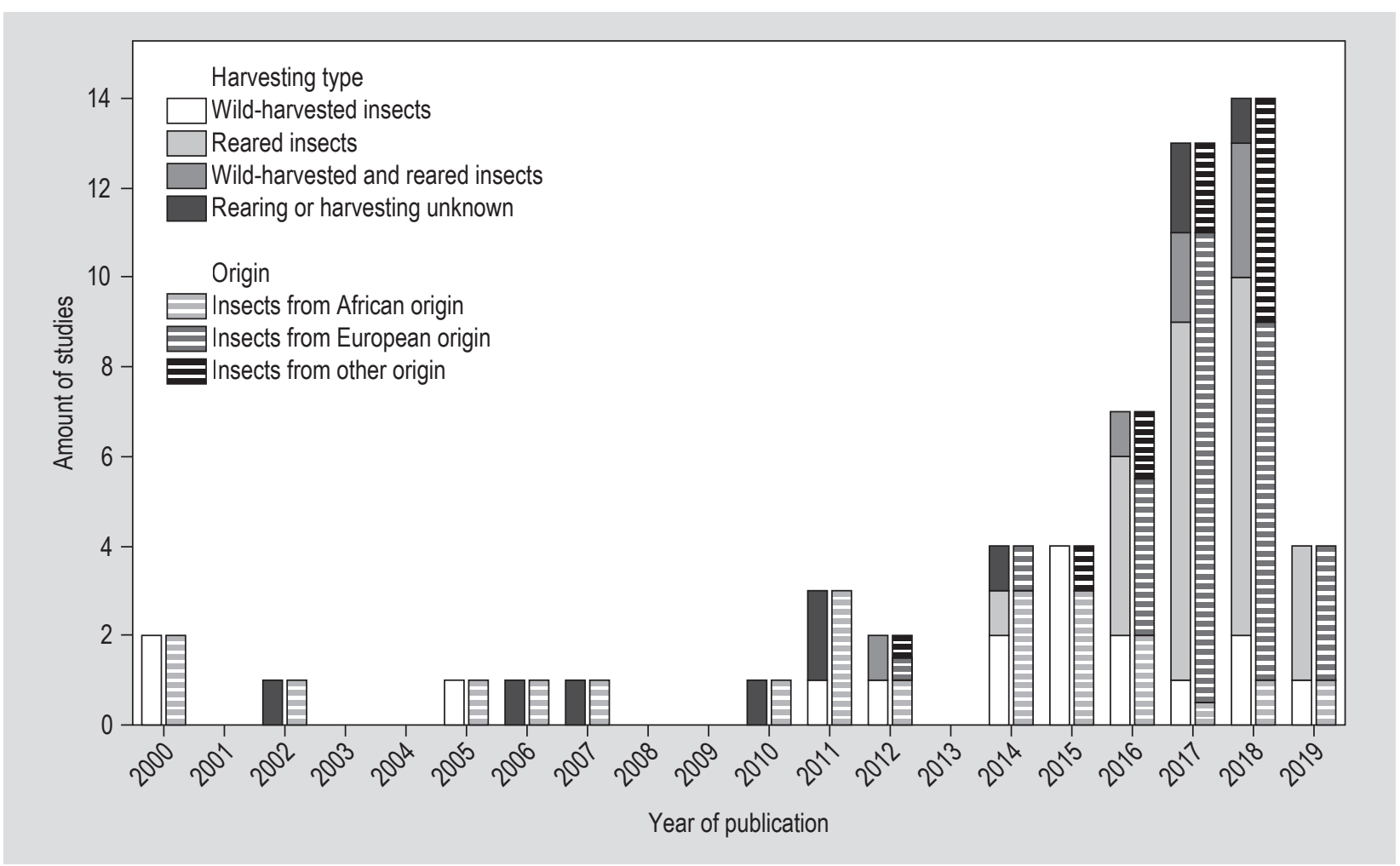

Figure 1. Amount of studies reporting microbiological data for insects for food between 2000 and 2019. Two graphs per year represent the reared or wild-harvested nature of the insects and the geographical origin of the insects, respectively, employed in the studies. Data were compiled from Garofalo et al. (2019) and supplemented with data from Kooh et al. (2019), Murefu et al. (2019) and Cappelli et al. (2020).

risks. Further, Cappelli et al. (2020) reported that prions and foodborne parasites and viruses can be considered as low risks and are not described yet in reared insects for human consumption.

Finally, a review article by Kooh et al. (2019) described the biological health risks associated with entomophagy. Pathogens reported by this study associated with the mentioned main five insect species are also included in Table 2. Using a more general, narrative approach, the authors came to similar conclusions as Garofalo et al. (2019), being that edible insects and derived products pose a low risk regarding Salmonella spp., Campylobacter spp., Yersinia spp., Vibrio spp., and L. monocytogenes. However, S. aureus was concluded to be very abundant in edible insects and spore formers such as Clostridium spp. and Bacillus spp. were reported to be of major concern. Especially members of the B. cereus group were presented as a substantial food safety hazard for insects as human food. Information regarding other foodborne biological contaminants (parasites, prions and viruses) was concluded to be scarce.

We can compile the aforementioned reviews and the studies they cover, to make overall conclusions on the state of the art in knowledge on the microbiological safety of insects for food. First, the currently available literature shows that barely any data are available regarding prions and foodborne viruses and parasites in insects farmed for human consumption. While certain microbiological risk assessments on edible insects (EFSA Scientific Committee, 2015; Fernandez-Cassi et al., 2018) claim that those biological contaminants present only a low safety risk, this has not been investigated yet. For foodborne viruses, however, a first effort was made in a very recent study (Vandeweyer et al., 2020a) which investigated the presence of Hepatitis A and E virus and Norovirus genogroup II in several raw insect samples collected from industrial producers. This research could confirm the low risk regarding those three viruses for the samples investigated, since none of the viruses were detected. In view of the recent outbreak of COVID-19, Dicke et al. (2020) investigated the transmission potential of edible insects for the zoonotic coronavirus SARS-CoV-2 (which does not appear to be foodborne so far), and concluded that hazard to be extremely low. Nonetheless, further research investigating other foodborne viruses and other insects, as well as research regarding prions and foodborne parasites is still required. Their fate during insect processing has also not been investigated so far. 
Table 2. Foodborne biological contaminants (bacteria and fungi) reported in edible insect species that pose a potential food safety risk. In the case only a genus name is mentioned, one or more species within that genus (other than a species that also may be listed) can be pathogenic.

\begin{tabular}{|c|c|c|c|}
\hline \multirow[t]{2}{*}{ Study } & \multirow[t]{2}{*}{ Insect species } & \multicolumn{2}{|c|}{ Potential foodborne biological safety risks identified } \\
\hline & & Bacteria & Fungi \\
\hline \multirow[t]{4}{*}{ Garofalo et al. (2019) } & Alphitobius diaperinus & Aeromonas, Bacillus, Pseudomonas & Aspergillus flavus, Aspergillus, Penicillium \\
\hline & Tenebrio molitor & $\begin{array}{l}\text { Bacillus cereus group, Bacillus, Clostridium } \\
\text { perfringens, Clostridium, Cronobacter, } \\
\text { Escherichia coli, Listeria }{ }^{1}, \text { Pseudomonas, } \\
\text { Salmonella }{ }^{2} \text { Staphylococcus aureus, } \\
\text { Staphylococcus, Vibrio, Yersinia }\end{array}$ & Penicillium \\
\hline & Acheta domesticus & $\begin{array}{l}\text { B. cereus group, Bacillus, C. perfringens, } \\
\text { Clostridium, Listeria }{ }^{1} \text {, Pseudomonas, } \\
\text { Staphylococcus }\end{array}$ & Aspergillus \\
\hline & Locusta migratoria & $\begin{array}{l}\text { Bacillus, C. perfringens, Pseudomonas, } \\
\text { Staphylococcus, Yersinia }\end{array}$ & Aspergillus \\
\hline \multirow[t]{5}{*}{ Kooh et al. (2019) } & A. diaperinus & & A. flavus \\
\hline & T. molitor & B. cereus group, C. perfringens, Clostridium & \\
\hline & A. domesticus & B. cereus group, C. perfringens & \\
\hline & L. migratoria & C. perfringens & \\
\hline & Edible insects in general & $\begin{array}{l}\text { Bacillus, B. cereus group, C. perfringens, } \\
\text { S. aureus }\end{array}$ & \\
\hline \multirow[t]{4}{*}{ Murefu et al. (2019) } & A. diaperinus & Bacillus, Clostridium & A. flavus, Aspergillus, Penicillium \\
\hline & T. molitor & $\begin{array}{l}\text { Bacillus, B. cereus group, Clostridium, } \\
\text { Escherichia, Listeria }{ }^{1} \text {, Pseudomonas, } \\
\text { Staphylococcus }\end{array}$ & Penicillium \\
\hline & A. domesticus & $\begin{array}{l}\text { Bacillus, B. cereus group, Clostridium, } \\
\text { Listeria', Staphylococcus }\end{array}$ & \\
\hline & L. migratoria & Staphylococcus & \\
\hline \multirow[t]{3}{*}{ Cappelli et al. (2020) } & A. diaperinus & & Aspergillus \\
\hline & T. molitor & $\begin{array}{l}\text { B. cereus group, Bacillus, C. perfringens, } \\
\text { Clostridium, Listeria }{ }^{1} \text {, Staphylococcus }\end{array}$ & \\
\hline & A. domesticus & $\begin{array}{l}\text { B. cereus group, Bacillus, C. perfringens, } \\
\text { Clostridium, Listeria }{ }^{1} \text {, Staphylococcus, } \\
\text { Yersinia }\end{array}$ & \\
\hline
\end{tabular}

Secondly, it is clear that the three major foodborne bacterial hazards in Europe, Salmonella spp., Campylobacter spp. and L. monocytogenes (Van Cauteren et al., 2017), are barely reported and consequently pose a low health risk for edible insects. Also Cronobacter spp., Vibrio spp. and Yersinia spp. are very rarely reported. However, the three main bacterial genera/species associated with food safety problems in edible insects are $S$. aureus, Clostridium spp., with the species $C$. perfringens and Clostridium botulinum being the most relevant food pathogens within this genus, and the B. cereus group. The B. cereus group, but also Clostridium spp., are spore-forming bacteria. This observation is noteworthy, since mitigation of the risks associated with bacterial endospores requires more drastic strategies than those for vegetative cells (Kort et al., 2005). As to mycotoxin-producing fungi, Aspergillus spp. and Penicillium spp. are noted as the most hazardous species. Also in the most recent studies (Borremans et al., 2019; Fernandez-Cassi et al., 2020; Frigerio et al., 2020; Mancini et al., 2019b), (some of) the same main biological safety hazards were addressed.

From all those risks, the presence of the B. cereus group can probably be ranked as the highest food safety risk 
for insects for human consumption. As demonstrated by multiple studies (Fasolato et al., 2018; Vandeweyer et al., $2018,2020 \mathrm{a}, \mathrm{b})$, the $B$. cereus group can be encountered in several insect species and derived products, sometimes in high amounts. The B. cereus group, or B. cereus sensu lato (s.l.), consists of a number of recognised species, including B. cereus sensu strictu (s.s.) and Bacillus thuringiensis (EFSA BIOHAZ Panel, 2016). All group members are genetically (and phenotypically) closely related to each other, and therefore no perfect distinction can be made between the members based on the $16 \mathrm{~S}$ ribosomal RNA gene (Ehling-Schulz et al., 2019). Moreover, their virulence for humans is very difficult to assess, since not all virulence genes (that could be used as marker gene for virulence) are known yet. Also, virulence appears to be very dependent on strain and environmental conditions (Jeßberger et al., 2015) and, as the known virulence genes are situated on (possibly mobile) plasmids, they can potentially be exchanged between members (SciCom, 2018). B. thuringiensis possesses a similar portfolio of potential virulence genes as $B$. cereus s.s. strains and is able to express them (EFSA BIOHAZ Panel, 2016). Therefore, $B$. thuringiensis, which is typically known as entomopathogen and can be a threat for the insect yield in mass production, can also be hazardous for humans.

When we look at the insect species that have been investigated with respect to microbiological food safety so far, the most important ones are T. molitor and A. domesticus. The other mealworm and cricket species, as well as L. migratoria are also being considered for human food (and novel food dossiers are submitted), but they were subjected to biological risk assessments to a much lesser extent. Hence, increased efforts to fill the knowledge gap for these particular species are encouraged. Moreover, also for the black soldier fly (H. illucens), a novel food dossier was submitted. While rarely considered as a food source in Europe (in contrast to certain Asian and African regions (Wang and Shelomi, 2017) and the discussion of its potential as food for the Pacific Small Islands Developing States (Shelomi, 2020)), biological safety of this species has not been described regularly in the context of human food. For animal feed, however, several studies have been performed, as detailed below.

\section{Biological risks associated with insects to be used in feed only}

In the EU, insects are considered farm animals and hence they are subjected to the EU 'feed ban' (Regulation (EC) No 999/2001; EC, 2001), which prohibits the use of farmed animal-derived proteins in feed for ruminant and monogastric animals. This effectively limited the use of insect proteins for a long time to applications in pet food or feed for fur animals. Since the $1^{\text {st }}$ of July 2017, the use of insect proteins from seven insect species in feed for aquaculture animals has been authorised (Regulation (EU) No 2017/893; EC, 2017). The exact species are black soldier fly, common housefly ( $M$. domestica), yellow mealworm, lesser mealworm, house cricket, tropical house cricket and field cricket (Gryllus assimilis). From these seven, only the common housefly and the black soldier fly are not commonly considered as human food and thus have not yet been discussed earlier in this review. Furthermore, these two species (together with the yellow mealworm) are the most generally used insects as protein source for animal feed globally. Hence, we will focus on the microbiological risks associated with these two species to assess the biological risks for insects as feed.

To identify which bacteria or fungi are most likely to cause problems, a clear view on the insect microbiota is needed. For the black soldier fly, this was long underexplored (De Smet et al., 2018), but a number of recent publications expand our understanding of the microbiota in the larvae on a variety of diets (Bruno et al., 2019; Jiang et al., 2019; Klammsteiner et al., 2020; Shelomi et al., 2020; Wu et al., 2020; Wynants et al., 2018; Zhan et al., 2020). These studies are more and more revealing the composition of the present microbiota in the larvae and the impact of substrate on its composition. Wynants et al. (2018) reported distinct sets of bacteria in the larvae and residue compared to the fed substrate. The same conclusion was drawn by Klammsteiner et al. (2020), who even more clearly hinted at the existence of a core set of microbes that make up the gut microbiota in the larvae, which may be established early on in larval development. Other studies show that microbes from the substrate can enter the gut and, if they are able to proliferate, become part of the gut microbiota, but they also state that these microbes never fully take control of this ecological niche (Bruno et al., 2019; Jiang et al., 2019). Bruno et al. (2019) for example reported variation in the bacterial species present in distinct regions of the gut, which is most likely due to the fact that each region represents a different ecological niche with other conditions. At the same time, the consensus is growing that a set of species is present in the larva, albeit to varying extent, during rearing on most of the tested diets to date, making them the core of the black soldier fly larvae (BSFL) gut microbiota. This core appears to include Actinomyces sp., Dysgonomonas sp., Enterococcus sp. and Morganella sp. These species have been found in other insects as well and could aid in the degradation of organic substances (Klammsteiner et al., 2020).

While the microbiota of the common housefly has been studied for individuals captured in the wild (Bahrndorff et al., 2017; De Jonge et al., 2020), to our knowledge no studies have been performed to assess its microbiota during an industrial rearing cycle, and therefore the microbiological quality cannot be compared to that of other insects for feed. 
When exploring specifically the presence of food pathogens, some studies do report potential risks in BSFL. Wynants et al. (2018) reported no detection of L. monocytogenes or coagulase-positive staphylococci. In contrast, they observed one contamination with Salmonella enterica serovar Agona in the rearing residue, but not in the larvae. Presumptive $B$. cereus was found in the larvae with counts up to 6,000 $\mathrm{cfu} / \mathrm{g}$. Other studies report the presence of Campylobacter (Wu et al., 2020) or Clostridium (Jiang et al., 2019) species in their metagenetics data but they did not quantify the actual pathogen load. Hence, the B. cereus group seems to be a major risk for insects for feed as well. With respect to other biological risks, e.g. prions and viruses, no data could be found that address safety questions for neither of both insect species. Only one report deals with the presence of a virus (be it not a food safety issue) in the BSFL gut: Chen et al. (2019) isolated a novel temperate Escherichia phage from the BSFL gut, and different substrates caused differences in phage induction. Hence, substrates may not only shape the gut microbiota directly, but also indirectly via their impact on lytic/lysogenic switches of phages infecting gut bacteria. For foodborne viruses, no information is available to our knowledge. Also, insects are, to date, not found to be able to produce prions, but prions can enter non-processed insects from contaminated substrates, for example slaughterhouse waste (EFSA Scientific Committee, 2015). This is a low level risk, that can be avoided by substrate quality control or preventing the feeding of these larvae to the same animal species as the one present in the substrate.

\section{Risk assessments on the transfer of biological contaminants during rearing of insects}

Biological safety risks are not only defined by the intrinsic presence or absence of pathogenic microorganisms. It is also important to estimate the risks for coincidental contamination during insect rearing or processing by a certain pathogen (EFSA Scientific Committee, 2015; Wynants et al., 2018). Studies that monitor the dynamics of a specific food pathogen when present in the substrate by inoculating the pathogen in the substrate (so-called challenge tests) are emerging in recent years (Belleggia et al., 2020; Mancini et al., 2019c; Wynants et al., 2019).

Almost all the available studies are about T. molitor and only some information on other species is available. Mancini et al. (2019c) detected a transmission of 3.6-4.6 log cfu/g of L. monocytogenes to mealworm larvae since the first day in the substrate at a load of $8 \log \mathrm{cfu} / \mathrm{g}$. This contamination seemed to persist for at least seven days. According to Belleggia et al. (2020), Listeria spp. can even multiply in the gut of the mealworm larvae. Because washing of the larvae did not cause a reduction in microbial counts, the bacteria were assumed to be present in the interior part of the larvae (Mancini et al., 2019c). This can cause considerable health risks when using the larvae, as a whole or after processing without degutting, as food or feed. Also Salmonella sp. can be transmitted to T. molitor already after one day and, if inoculated at $7 \mathrm{log} \mathrm{cfu} / \mathrm{g}$ in the substrate, the contamination was still present after seven days (Wynants et al., 2019). BSFL have also been subjected to several challenge studies. Defilippo et al. (2018) determined that larvae contain the same concentration of $S$. enterica serovar Typhimurium (3-4 log cfu/g) and L. monocytogenes (5-6 log $\mathrm{cfu} / \mathrm{g}$ ) as the inoculated substrate, but they observed a 2-log decreased concentration when reaching the pupal stage. No hypothesis for this observation was given. Swinscoe et al. (2020) observed a stable concentration of L. monocytogenes and Vibrio parahaemolyticus (6 log cfu/g) and a slightly decreasing concentration of Escherichia coli and E. coli O157:H7 (from $7 \log \mathrm{cfu} / \mathrm{g}$ to $5 \mathrm{log} \mathrm{cfu} / \mathrm{g}$ ) over a period of seven days after exposure to a contaminated substrate. The authors mention that a selective inactivation (i.e. some strains are inhibited while others are not) of the pathogens by the larvae occurs via exposure to antimicrobials (showing a certain selectivity). In particular, the expression of antimicrobial peptides by BSFL is substantial in proteinrich diets, as the seaweed-based diet used in their study. Although pathogen transfer does not necessarily affect the viability of the larvae in a negative way (Mancini et al., 2019c), it can be a risk when using these contaminated larvae for food or feed purposes. However, it is worth noting that the results observed seem to depend on numerous factors, such as pathogen level in the substrate and stage in the cycle of the insect, and thus general conclusions cannot be extrapolated to other combinations of insect and pathogen species.

Even though a number of challenge tests were performed for bacteria, transfer of other biological risks, such as prions, viruses, fungi and parasites, is much less investigated. One recent study on transmission of parasites via BSFL feed (Müller et al., 2019) revealed a transfer of less than $1 \%$ of the parasital oocysts of Eimeria nieschulzi, Eimeria tenella or eggs of Ascaris suum in the larval gut. No or very low contamination was found in the prepupal stages. Nevertheless, it is still too early to neglect the potential risk of parasite transmission when using BSFL as animal feed. Next to parasites, a study from Varotto Boccazzi et al. (2017) investigated the transfer of fungi to BSFL reared on chicken feed and vegetable waste, with both substrates causing a different fungal community in the larvae. Larvae grown on chicken feed contained mainly Trichosporon, Rhodotorula and Geotrichum species, whereas in vegetable waste fed larvae, Pichia was the most abundant genus.

Besides challenge tests with contaminated substrates, also indirect exposure of insects to human pathogens has been studied. For the housefly ( $M$. domestica), studies exist that focus on wild flies. One such study confirmed the transfer of different pathogens by exposure to facilities containing 
contaminated farm animals. About $20 \%$ of the flies caught on broiler farms were positive for Salmonella (Bailey et al., 2001), and even more than 50\% tested positive after 4 to 7 days exposure to environments housing S. enterica serovar Enteritidis challenged hens (Holt et al., 2007). In another study, Campylobacter sp. could be isolated from about 40 to $50 \%$ of the flies sampled on chicken farms and piggeries (Rosef and Kapperud, 1983). These studies also demonstrate that rearing of the common housefly should take place in clean conditions as contaminations of the feed are very likely to enter the insect.

Despite the fact that various biological risks can be transferred to insects, some species seem to be able to reduce or even eliminate specific bacteria in their substrate. They can therefore be reasoned to decrease the biological risk. For instance, BSFL have shown to be able to reduce the amount of Enterobacteriaceae. A reduction of S. enterica serovar Enteritidis (3.5-5.5 log reduction after two days) and E. coli O157:H7 (1.5-5 log reduction after two days and even below detection limit after three days) in chicken manure has been observed (Erickson et al., 2004). Also Liu et al. (2008) and Lalander et al. (2013) found a reduction of respectively $E$. coli by 5-7 log cycles in dairy manure and of Salmonella spp. by 7 log cycles in eight days in faecal sludge. Lalander et al. (2015) studied the reduction of Salmonella spp. and Enterococcus spp. in a mixture of pig manure, human faeces and dog food. For Salmonella spp., the concentration in the substrate was reduced from approximately 7 to less than $1 \mathrm{cfu} / \mathrm{g}$ after two weeks, while Enterococcus contamination remained unchanged. Those experiments could be interpreted as promising perspectives for a safe recycling of animal or human manure by BSFL. Nevertheless, according to (EC) No. 1069/2009, the use as substrate of manure, catering waste and former foodstuff containing meat or fish is forbidden for farmed animals, including insects destined for food and feed purposes. So far, the pathogen-reducing effects of BSFL have not been studied and confirmed enough to alter legislation. It is not known, for instance, whether the effects are substrate-dependent or not. More data may help to finetune legislation on this aspect in the future.

\section{Mitigation strategies to reduce food and feed safety risks}

As is clear from literature, the high microbial counts associated with untreated edible insects and the possible occurrence of certain pathogenic microorganisms require suitable mitigation strategies, i.e. strategies to reduce the microbiological risks, to be applied on the insects in order to ensure safety. The four reviews on insects for food referred to before discuss studies that report on treatments to reduce microbiological safety risks (Table 1). Altogether, thermal treatments such as boiling, roasting, (deep-)frying and blanching, even for short times, have proven to be very effective to reduce the amount of vegetative bacteria and fungi. Alternative treatments such as fermentation, cold plasma treatments, microwave drying may also reduce microbiological food safety risks. For example, a recent study investigated the efficacy of high hydrostatic pressure (HHP) to reduce certain microbiological risks in a meal derived from dried BSFL (Kashiri et al., 2018). They reported that Listeria was not present in the extract, but Salmonella and E. coli were found at around 5 to $6 \log \mathrm{cfu} / \mathrm{g}$. The killing efficacy of a HHP treatment at $400 \mathrm{MPa}$ for 7 minutes was the highest for yeasts and moulds (no survivors), but had hardly any effect on the count of naturally present total aerobic mesophilic bacteria ( $0.35 \log$ reduction). No data were provided on the reduction of Salmonella. However, the treatment did reduce the load of inoculated E. coli with $6.56 \log$ cycles (Kashiri et al., 2018). The fact that this technology was less effective against naturally present bacteria than against inoculated $E$. coli is hypothesised to be due to the presence of bacterial endospores. This is an important factor, as the B. cereus group is considered as a high risk. Non-thermal drying methods such as freezedrying, which is commonly used in the insect industry, only have a microbiostatic effect and are therefore not sufficient to assure microbiological food safety. Starvation of the insects at the end of the rearing cycle may be thought to have the effect of emptying the gut and hence clearing the insects from pathogens as well, but starvation should not be considered as a mitigation strategy since the effect on the microbiota appears to vary for different studies (Mancini et al., 2019a,b; Wynants et al., 2017).

\section{Future challenges and research needs for biological safety of edible insects}

\section{Focus needed on individual insect species}

In the same way as the gut microbiome is not equal for all traditional farm animals, it is not accurate to make general statements on the microbiota of edible insects altogether. Risk profiles and assessments should envisage individual species, such as the risk profile for $A$. domesticus by Fernandez-Cassi et al. in 2018 and in 2019, in order to identify and implement species-specific hygiene measures during rearing. When organising studies that focus on an individual insect species, care should be taken to include samples obtained from industrial producers rather than from insects reared in laboratory conditions. To obtain a representative view on the microbiota and on food pathogens during mass rearing of insects, it is necessary to involve several producers, hence covering differences in substrates and production processes applied on different locations, as done for instance by Wynants et al. (2019). In addition, per producer several batches or rearing cycles need to be sampled using proper sampling plans, as detailed below. Batches are ideally produced over a time span of several months to capture possible variations over time in 
substrate quality and seasonality, environmental conditions and rearing procedures. Such studies are extensive, but allow to describe possible correlations between the microbiota including the occurrence of biological contaminants on the one side and rearing conditions (feed, environmental conditions, hygiene practices and house flora, etc.) on the other side.

To supplement and deepen species-specific risk assessments, the behaviour of certain biological contaminants during the life cycle of an insect can be studied as mentioned before by challenge tests. Deliberately infecting insects at a certain stage in their development with a known and standardised concentration of the pathogen allows to investigate if and how fast the contaminant is taken up by insect specimens (horizontal transfer). Also, it can be monitored where it is located in the gut and how passage through the gut occurs, how fast it is spread between specimens, whether it can grow in the substrate and/or insect or whether it naturally dies or maybe is actively eradicated by the insect. As discussed above, some combinations of insect and pathogen species have been investigated in this way, but a number of relevant insect-pathogen combinations have not been investigated so far. Especially for the main biological risks identified, B. cereus, Clostridium spp. and $S$. aureus, such data are still lacking for insects for food and feed. Overall, there is still a gap in the knowledge in the behaviour of biological contaminants that can be present in side or waste streams or that can be transmitted via personnel, i.e. Bacillus, Campylobacter, Clostridium, Listeria, Salmonella, and Staphylococcus during rearing of mass produced insects. Bacillus and Clostridium are two spore-forming bacterial species, and studies ideally involve both vegetative cells as well as spores. To the best of our knowledge, studies on vertical transmission of food pathogens, i.e. from one cycle to the next over the egg phase, are not yet available. It is not known so far whether the eggs can be a route by which food pathogens are introduced in a batch of larvae or nymphs. At least for H. illucens, it is thinkable that food pathogens may follow this transmission route, because bacterial communities including Bacillus sp. have been shown to be stimulating for oviposition (Yu et al., 2011; Zheng et al., 2013).

Also post-harvest decontamination and preservation strategies should be designed specifically for each individual species. A heat treatment comprises both a time and a temperature for the slowest heating point in the material to be treated. Inactivation kinetics cannot simply be extrapolated from one insect(-based product) to another, because: (1) heat transfer in a matrix depends on the composition (water content, fat content, etc.) and structure (whole insects, finely mixed paste or powder, or roughly grinded and hence containing air pockets) of the matrix; and (2) because individual insect species are characterised by other levels and types of target microorganisms. In the end, the time-temperature combination is to be determined to reduce the load of the most significant target organism in an insect matrix in a sufficient way, which is in the food industry often a reduction with 6,8 or $12 \log$ cycles. For inactivation strategies that do not use heat, also process parameters need to be defined for the matrix to be treated, i.e. a specific insect species, to obtain the same required reduction. Research to unravel the survival of spore-forming bacteria in post-harvest treatments preferably includes both vegetative cells as well as spores. While it may not be possible due to too much quality deterioration to eliminate all spores, heat treatments should not have the side effect of activating the spores, and if spores are observed to survive a treatment, then care should be taken to provide conditions during further storage and transport of the treated insect(-based product) that impede spore germination, such as (sufficient) refrigeration and/or acidification. As described before, a number of studies exist for particular species investigating the effect of heat or other treatments, but no general recommendations exist. Likely, knowledge and expertise is established in insect-processing companies and not (yet) publicly available.

\section{Specific attention on substrate, residue and house flora}

Not only the insects need further microbiological characterisation, also substrates should be characterised for their typical microbial profile, their core microbiota, if any, and their so-called specific spoilage organisms (SSO; Man and Jones, 2000). In the context of side stream storage, SSOs are those (subgroups of) microorganisms (bacteria, yeasts, moulds) that will dominate the microbiota when these organic streams are stored in insect production facilities and by their metabolism cause spoilage phenomena as off-odours and flavours. Side streams are often given one or more pre-treatment steps prior to be fed to the insects, such as mixing, concentration by a heat or alternative treatment, milling, acidification and so on. Those are all unit operations that can have an effect on the microbial load of the substrate, by either a killing effect or conversely improving conditions for microbial growth, and in turn on the insects reared on them. The impact on food pathogens that can occur in (mixtures of) organic side streams of the currently used preparation technologies is not yet thoroughly investigated. The effect of time-temperature conditions on survival of food pathogens inoculated in the substrate matrices at several contamination levels should be documented. Similar as to insect processing, this may have been studied to some extend by companies, but information in literature is missing.

The residue remaining after harvesting insects, containing unconsumed substrate, insect faeces or frass, and/or exuviae, offers the potential to be upcycled as soil fertiliser or plant growth supplement (Houben et al., 2020). At least in the EU, legislation is not harmonised yet, and different 
member states impose other inactivation conditions. Several (microbiological) questions are being discussed by researchers, authorities and stakeholders. According to Regulation (EU) No 142/2011 (EC, 2011), so-called 'Method 1 to 5' (describing time, temperature and pressure combinations related to specific particle sizes of the material to be treated) or 'Method 7' may be used for the hygiene of residual fractions from insect rearing. Methods 1 to 5 apply to materials with a certain particle size, but in insect rearing the particle size of the residual fraction can vary or is not always known by producers. Method 7 allows the development of a treatment that can be shown to result in the achievement of certain microbiological criteria for C. perfringens, Salmonella and Enterobacteriaceae. While Method 7 leaves room for insect producers to optimise their own processing method, in Europe there is a general interest to equalise the processing conditions for insect residue with those valid for animal manure, i.e. heat treatment of $70{ }^{\circ} \mathrm{C}$ for one hour (IPIFF, 2019a). A next step could then be to assess whether less stringent parameters and non-thermal inactivation strategies (that better preserve the chemical quality of the residue) can still warrant compliance with the safety standards. This requires inactivation trials with inoculated residues and results will be insect-specific, since the composition of the residue is also species-specific.

In the insect sector, the impact of the house flora in a rearing and/or processing company on the microbiological safety of the end product is pretty much uncharted terrain. Numbers of microorganisms present on food contact surfaces in food companies are known to increase during production and to be reduced during proper cleaning and disinfection (Holah, 2014). While these organisms were first only thought to be responsible for spoilage problems, they are now also known to be related to safety issues. Pathogens can interact with and grow in biofilms, and in a production environment a persistent house flora that is pathogenic can develop (Holah, 2014). For example, it has been demonstrated that the composition of the resident microorganisms on a surface, or the house flora, can either promote or inhibit the growth of L. monocytogenes in the biofilm, and hence determine whether a surface can be a contamination route for a pathogen or not (Carpentier and Chassaing, 2004). In the insect industry, research is needed on the potential of food pathogens to reside in the production environment or not, and whether the environment can in this way be part of the transmission routes for a pathogen or not. Investigating the house flora in an insect production plant can be of support in the implementation of a hazard analysis and critical control points (HACCP) plan, which will also be discussed below. The application of a HACCP plan is based on 7 principles and consists of 12 steps (FAO/WHO, 2009). In step 6, all potential hazards should be listed that may reasonably be expected to occur in the whole process line. If the composition of the house flora is known for several surfaces in the production site, it is also known whether these communities can harbour pathogens (and which ones, at what level and at what specific locations). Next, potential transfer from the environment to the insect(-products) can be assessed. If relevant, the transfer can be identified as a hazard and implemented in the determination of critical control points, in particular related to the cleaning and disinfection practices (step 7).

\section{Proper sampling plans and predictive microbiology for knowledge extension}

Whether it is in the investigation of microbiological quality of insects themselves, or of substrates, residue or the production environment, a central question is always how to construct a proper sampling plan. Insect producers are responsible for the microbiological safety of their products and have to make sure their products fulfil national and international compulsory microbiological criteria, as summarised in the IPIFF guide on good hygiene practices (IPIFF, 2019b). While these criteria may still be refined in the future, the challenge behind these targets for insect producers is how to convert those requirements (legal, or maybe even more stringent Business-toBusiness agreements between producer and buyer) into practices, measures and interventions, that determine the microbiological quality during production (and hence also may evolve and be fine-tuned) in order to warrant the achievement of the targets for the end product. In the context of the food industry, Jacxsens et al. (2009) defined such 'company specific set of control and assurance activities to realise and guarantee food safety' as a food safety management system (FSMS). An FSMS should translate good hygienic practices and the HACCP system in the specific context of the company (De Loy-Hendrickx et al., 2018). Jacxsens et al. (2009) also described a microbial assessment scheme (MAS) to investigate the microbial performance of such FSMS, i.e. to find out whether the correct sampling locations are identified, whether the most relevant microbiological parameters are selected, and to assess the sampling and analytical methods. A MAS has been applied to assess the microbiological performance of integral production and processing chains of e.g. lamb (Osés et al., 2012), pangasius (Tong Thi et al., 2014) and in Kenyan fresh produce processing and export companies (Kamau Njage et al., 2017), but this exercise would also be useful for insect companies. Moreover, the subdomain in food microbiology of predictive microbiology, in which mathematical models predict the growth, survival, spore germination and toxin production of pathogens in a certain food matrix, is completely unexplored so far for insects, but can certainly bring new insights. 


\section{Microbiological methods: standardisation and dealing with the unculturable fraction}

As one of its future tasks, the Commission on Insects of the European Federation for Animal Science (formerly European Association for Animal Production or EAAP) has decided to work on the standardisation of research methods. This is also pertinent for microbiological methods. Not only the media and incubation conditions used influence the result, but for insects it was shown that whether or not pulverising a sample prior to preparing a dilution series can make a difference in the count of even 1.6 to $2.2 \log \mathrm{cfu} / \mathrm{g}$ (Vandeweyer et al., 2017). Also, for culture-dependent microbial counts, it is a prerequisite that samples are investigated immediately after sampling or at the latest after one day storage under refrigerated conditions (rather than after frozen storage of samples). This is a practice that is unequivocal in microbiological food analysis, but it may not yet be understood and followed by all insect producers.

In colony counting, the incubation step entails a limitation since only a fraction of the microbiota is known to be culturable. Barcina and Irana (2009), as cited by Fakruddin et al. (2013), state that in water and soil samples from nature, less than $1 \%$ of the microorganisms is culturable. For insects used in food and feed, the share of the culturable fraction in the total microbiota has not been estimated so far. Moreover, within the field of food microbiology, special attention is paid to food pathogens that can enter a viable but nonculturable (VBNC) state, implying that their cells cannot grow on culture media but they still show metabolic activity as described for the first time by Xu et al. (1982). Recently, Zhao et al. (2017) presented a list of 35 foodborne pathogens that were proven to show this state, many species of which have already been identified on edible insects. From the review by Zhao et al. (2017), it appears that the VBNC state can be induced by bringing viable cells in stress conditions, such as in several food treatments relevant for insect processing as well (heating, cooling, drying). Based on their literature review, the authors also conclude that some pathogens retain their pathogenicity (as shown in animal models) while others are avirulent. Microscopic counting and molecular technologies are under development to assess VBNC food pathogens, and this is a new field in the microbiological safety of edible insects, too.

Culture-independent methodologies do not comprise an incubation step in which microorganisms are required to grow in order to quantify or detect them in a next step. Culture-independent analyses can be either a metagenetic analysis, as defined earlier, or they accomplish the amplification (and subsequent detection or quantification) of target sequences of DNA (or RNA) of particular microbial species, such as food pathogens (i.e. PCR technology). Metagenetics provides a more comprehensive overview of the microbial composition of an insect sample than plate counting does, and, as reviewed by Garofalo et al. (2019), the technology is increasingly being incorporated in studies characterising the insect microbiota during rearing and processing. Mostly metagenetics is DNA-based, although Bruno et al. (2019) worked on the RNA level (i.e. metatranscriptomics). Since RNA is known to disintegrate faster after cell death in contrast to DNA, it is considered as a good target to selectively focus on living cells. In terms of interpretation of microbiological safety, (DNA-based) metagenetics is limited in that it only demonstrates the presence of DNA, rather than the presence of viable and virulent food pathogens. DNA of dead cells is also detected by sequencing analyses, yet it does not always point towards a food safety problem. Conversely, processing of insects may destroy DNA, thereby eliminating the possibility to detect pathogens, which, even though the viable cells may have been inactivated by processing, may have produced toxic metabolites that were resistant to the processing conditions applied (such as the cereulide by B. cereus). In addition, Filippidou et al. (2015) mentioned that bacterial endospores can resist to DNA extraction and remain under-detected, even when applying methods specially developed to tackle spores. Hence, metagenetics proves its value to some extent in delivering a general overview of the microbial community composition in an insect sample. Meaningful detection (in terms of food safety assessment) of particular food pathogens can also be based on PCR techniques, preferably either Reverse Transcriptase-PCR starting from RNA, or PCR targeting DNA from living cells by first blocking DNA from dead cells using propidium monoazide (PMA) or ethidium monoazide (EMA). For example, Abd El-Aziz et al. (2018) examined three hundred fresh and processed samples of traditional meat purchased in Egyptian supermarkets for the presence of a variety of food pathogens. By applying PMA quantitative realtime PCR, they discovered that $90.48 \%$ of the culturenegative meat samples contained a high load of a range of VBNC food pathogens, being a strong threat to public health. To the best of our knowledge, such approach has not been applied to evaluate the microbiological safety of insect(-based feed or food)s, but as in previous PMA/EMA studies, a lot of interference of the matrix can be expected.

\section{Microbiological challenges related to the further development of the sector}

Edible insects are increasingly being proposed as alternative protein source, with the term 'alternative' often alluding to 'more sustainable' than traditional sources. The sector wants to maximise the sustainability of rearing and processing steps, as can be evaluated in life cycle assessment studies. One aspect in this context is the limitation or avoidance of energy consuming unit operations, such as conventional thermal treatments or freeze-drying, and their replacement by innovative thermal technologies 
such as microwave or ohmic heating or non-thermal treatments (high hydrostatic pressure, pulsed electric fields, low energy electron beam, intense light pulses, cold plasma, etc.). From a microbiological perspective, those technologies can involve the risk of a reduced food safety when not properly investigated and applied. Not only should process parameters be established that sufficiently reduce the target pathogens that are known so far to be relevant for insect(-product)s, but also the emergence of new microbiological food safety problems should be avoided. The design of a treatment to ensure minimal processing often comprises the combination of multiple decontamination actions to achieve the same reduction as a single lethal stress (Rosnes et al., 2011). For traditional foods, during the past decades many cases are elaborated based on this combination strategy, but insects are a new matrix to be studied.

In its aim to maximally contribute to upcycling and to a circular economy, the sector hopes for green light to grow insects on low value substrates, such as unprocessed former foodstuff (preconsumer waste) containing meat and fish, postconsumer waste (i.e. catering waste), slaughterhouse waste and, for certain continents, manure. This is reflected for instance in the advice recently formulated by the Netherlands Food and Consumer Product Safety Authority (Anonymous, 2020) to rear insects on former foodstuffs containing meat, which is not allowed today. It goes without saying that feeding these lower value substrates eventually may be linked to (new) biological safety risks, when feeding these streams to insects, fresh or - implying an even larger risk - after storage. Taking this next step requires making an inventory of the food pathogens that can occur in these streams and an investigation of their behaviour in these matrices and of the efficiency of hygienisation practices.

Finally, the insect sector is rapidly growing, both in terms of number of companies as in terms of average company scale. This is demonstrated for Europe in a Factsheet of June 2020 composed by IPIFF (2020): in Europe 6,000 tonnes of insect proteins were produced by its members in 2019 and production is estimated to be around 3 million tonnes in 2030. Hence, the insect supply chain becomes more complex, involving more suppliers, intermediate B2B activities, and with an increasing intermediate and finished product portfolio, a more complex distribution network due to an increasing number and type of clients. For the traditional food industry, Martins et al. (2014) exhaustively elaborated on how an increasing complexity and upscaling of food production impacts the prevalence of zoonoses and complicates safety control. It is valid to extrapolate this challenge to the insect sector as well. A sector producing higher volumes and more diverse products will go hand in hand with more comprehensive sampling plans, new critical control points, a thorough traceability, longer transport and storage times, and these are all aspects to be considered from a microbiological viewpoint. This challenge may even be the most important from all challenges, since the relatively young sector definitely needs to avoid the occurrence of food crises and to show the expertise is present to accomplish the safety goals, in order to maintain and even further establish its position.

\section{Acknowledgements}

The authors wish to thank R. Smets for his assistance in the design of the figures. DV is financed by the Research Foundation - Flanders (FWO) via the SBO project ENTOBIOTA (S008519N) as well as by the European Union's Horizon 2020 Research and Innovation programme via the H2020 project SUSINCHAIN (grant agreement number 861976). JDS holds a postdoctoral fellowship grant (grant number 12V5219N) of the FWO. NVL is PhD researcher on the ERANET FACCE SURPLUS project UpWaste (ID 28) funded by FWO.

\section{Conflict of interest}

The authors declare no conflict of interest.

\section{References}

Abd El-Aziz, N.K., Tartor, Y.H., Abd El-Aziz Gharib, A. and Ammar, A.M., 2018. Propidium monoazide quantitative real-time polymerase chain reaction for enumeration of some viable but nonculturable foodborne bacteria in meat and meat products. Foodborne Pathogens and Disease 15: 226-234. https://doi.org/10.1089/ fpd.2017.2356

Anonymous, 2020. Advice on animal and public health risks of insects reared on former foodstuffs as raw material for animal feed. Netherlands Food and Consumer Product Safety Authority, Utrecht, the Netherlands, 60 pp. Available at: https://english. nvwa.nl/documents/consumers/food/safety/documents/adviceon-animal-and-public-health-risks-of-insects-reared-on-formerfoodstuffs-as-raw-material-for-animal-feed

Bahrndorff, S., De Jonge, N., Skovgård, H. and Nielsen, J.L., 2017. Bacterial communities associated with houseflies (Musca domestica L.) sampled within and between farms. PLoS ONE 12: e0169753. https://doi.org/10.1371/journal.pone.0169753

Bailey, J.S., Stern, N.J., Fedorka-Cray, P., Craven, S.E., Cox, N.A., Cosby, D.E., Ladely, S. and Musgrove, M.T., 2001. Sources and movement of Salmonella through integrated poultry operations: a multistate epidemiological investigation. Journal of Food Protection 64: 16901697. https://doi.org/10.4315/0362-028X-64.11.1690

Barcina, I. and Arana, I., 2009. The viable but nonculturable phenotype: a crossroads in the life-cycle of non-differentiating bacteria? Reviews in Environmental Science and Biotechnology 8: 245-255. https:// doi.org/10.1007/s11157-009-9159-x 
Belleggia, L., Milanović, V., Cardinali, F., Garofalo, C., Pasquini, M., Tavoletti, S., Riolo, P., Ruschioni, S., Isidoro, N., Clementi, F., Ntoumos, A., Aquilanti, L. and Osimani, A., 2020. Listeria dynamics in a laboratory-scale food chain of mealworm larvae (Tenebrio molitor) intended for human consumption. Food Control 114: 107246. https://doi.org/10.1016/j.foodcont.2020.10724.6

Borremans, A., Crauwels, S., Vandeweyer, D., Smets, R., Verreth, C., Van der Borght, M., Lievens, B. and Van Campenhout, L., 2019. Comparison of six commercial meat starter cultures for the fermentation of yellow mealworm (Tenebrio molitor) paste. Microorganisms 7: 540. https://doi.org/10.3390/ microorganisms7110540

Bruno, D., Bonelli, M., De Filippis, F., Di Lelio, I., Tettamanti, G., Casartelli, M., Ercolini, D. and Caccia, S., 2019. The intestinal microbiota of Hermetia illucens larvae is affected by diet and shows a diverse composition in the different midgut regions. Applied and Environmental Microbiology 85: e01864-18. https://doi.org/10.1128/ AEM.01864-18

Cappelli, A., Cini, E., Lorini, C., Oliva, N. and Bonaccorsi, G., 2020. Insects as food: a review on risks assessments of Tenebrionidae and Gryllidae in relation to a first machines and plants development. Food Control 108: 106877. https://doi.org/10.1016/j. foodcont.2019.106877

Carpentier, B. and Chassaing, D., 2004. Interactions in biofilms between Listeria monocytogenes and resident microorganisms from food industry premises. International Journal of Food Microbiology 97: 111-122. https://doi.org/10.1016/j.ijfoodmicro.2004.03.031

Chen, Y., Li, X., Song, J., Yang, D., Liu, W., Chen, H., Wu, B. and Qian, P., 2019. Isolation and characterization of a novel temperate bacteriophage from gut-associated Escherichia within black soldier fly larvae (Hermetia illucens L. [Diptera: Stratiomyidae]). Archives of Virology 164: 2277-2284. https://doi.org/10.1007/s00705-01904322-w

De Jonge, N., Yssing Michaelsen, T., Ejbye-Ernst, R., Jensen, A., Elley Nielsen, M., Bahrndorff, S. and Lund Nielsen, J., 2020. Housefly (Musca domestica L.) associated microbiota across different life stages. Nature 10: 7842. https://doi.org/10.1038/s41598-020-64704-y De Loy-Hendrickx, A., Debevere, J., Devlieghere, F., Jacxsens, L., Uyttendaele, M. and Vermeulen, A., 2018. Microbiological guidelines: support for interpretation of microbiological test results of foods. Die Keure, Brugge, Belgium, 478 pp.

De Smet, J., Wynants, E., Cos, P. and Van Campenhout, L., 2018. Microbial community dynamics during rearing of black soldier fly larvae (Hermetia illucens) and impact on exploitation potential. Applied and Environmental Microbiology 84: e02722-17. https:// doi.org/10.1128/AEM.02722-17

Defilippo, F., Grisendi, A., Listorti, V., Dottori, M. and Bonilauri, P., 2018. Black soldier fly larvae reared on contaminated substrate by Listeria monocytogenes and Salmonella. Available at: https:// meetings.eaap.org/wp-content/uploads/2018/Session47/47.16_ aq9i52ws.pdf

Dicke, M., Eilenberg, J., Falcao Salles, J., Jensen, A.B., Lecocq, A., Pijlman, G.P., Van Loon, J.J.A. and Van Oers, M.M., 2020. Edible insects unlikely to contribute to transmission of coronavirus SARSCoV-2. Journal of Insects as Food and Feed 6(4): 333-339. https:// doi.org/10.3920/JIFF2020.0039
European Commission (EC), 2001. Regulation (EC) No 999/2001 of the European Parliament and of the Council of 22 May 2001 laying down rules for the prevention, control and eradication of certain transmissible spongiform encephalopathies. Official Journal L 147: 1-40.

European Commission (EC), 2005. Commission Regulation (EC) No 2073/2005 of 15 November 2005 on microbiological criteria for foodstuffs. Official Journal L 338: 1-26.

European Commission (EC), 2011. Commission Regulation (EU) No 142/2011 of 25 February 2011 implementing Regulation (EC) No 1069/2009 of the European Parliament and of the Council laying down health rules as regards animal by-products and derived products not intended for human consumption and implementing Council Directive 97/78/EC as regards certain samples and items exempt from veterinary checks at the border under that Directive. Official Journal L 54: 1-254.

European Commission (EC), 2015. Regulation (EU) No 2015/2283 of the European Parliament and of the Council of 25 November 2015 on novel foods. Official Journal L 327: 1-22.

European Commission (EC), 2017. Commission Regulation (EU) No 2017/893 of 24 May 2017 as regards the provisions on processed animal protein. Official Journal L 138: 92-116.

European Food Safety Authority Panel on Biological Hazards (EFSA BIOHAZ Panel), 2016. Scientific opinion on the risks for public health related to the presence of Bacillus cereus and other Bacillus spp. including Bacillus thuringiensis in foodstuffs. EFSA Journal 14: 4524. https://doi.org/10.2903/j.efsa.2016.4524

European Food Safety Authority Scientific Committee, 2015. Risk profile related to production and consumption of insects as food and feed. EFSA Journal 13: 4257. https://doi.org/10.2903/j.efsa.2015.4257

Ehling-Schulz, M., Lereclus, D. and Koehler, T.M., 2019. The Bacillus cereus group: Bacillus Species with pathogenic potential. Microbiology Spectrum 7(3). https://doi.org/10.1128/microbiolspec. gpp3-0032-2018

Erickson, M.C., Islam, M., Sheppard, C., Liao, J. and Doyle, M.P., 2004. Reduction of Escherichia coli O157:H7 and Salmonella enterica serovar Enteritidis in chicken manure by larvae of the black soldier fly. Journal of Food Protection 67: 685-690. https:// doi.org/10.4315/0362-028x-67.4.685

Fakruddin, M., Bin Mannan, K.S. and Andrews, S., 2013. Viable but nonculturable bacteria: food safety and public health perspective. International Scholarly Research Notices: Article ID 703813.. https:// doi.org/10.1155/2013/703813

Fasolato, L., Cardazzo, B., Carraro, L., Fontana, F., Novelli, E. and Balzan, S., 2018. Edible processed insects from e-commerce: food safety with a focus on the Bacillus cereus group. Food Microbiology 76: 296-303. https://doi.org/10.1016/j.fm.2018.06.008

Fernandez-Cassi, X., Söderqvist, K., Bakeeva, A., Vaga, M., Dicksved, J., Vagsholm, I., Jansson, A. and Boqvist, S., 2020. Microbial communities and food safety aspects of crickets (Acheta domesticus) reared under controlled conditions. Journal of Insects as Food and Feed 6: 429-440. https://doi.org/10.3920/jiff2019.0048

Fernandez-Cassi, X., Supeanu, A., Jansson, A., Boqvist, S., Vagsholm, I., Boqvist, S. and Vagsholm, I., 2018. Novel foods: a risk profile for the house cricket (Acheta domesticus). EFSA Journal 16: e16082. https://doi.org/10.2903/j.efsa.2018.e16082 
Fernandez-Cassi, X., Supeanu, A., Vaga, M., Jansson, A., Boqvist, S. and Vagsholm, I., 2019. The house cricket (Acheta domesticus) as a novel food: a risk profile. Journal of Insects as Food and Feed 5: 137-157. https://doi.org/10.3920/JIFF2018.0021

Filippidou, S., Junier, T., Wunderlin, T., Lo, C.C., Li, P.E., Chain, P.S. and Junier, P., 2015. Under-detection of endospore-forming firmicutes in metagenomic data. Computational and Structural Biotechnology Journal 13: 299-306. https://doi.org/10.1016/j.csbj.2015.04.002

Food and Agriculture Organisation / World Health Organisation (FAO/ WHO), 2009. Hazard analysis and critical control point (HACCP) system and guidelines for its application. Food hygiene basic texts, $4^{\text {th }}$ edition. Joint FAO/WHO Food Standards Programme, Codex Alimentarius Commission, Rome, Italy.

Frigerio, J., Agostinetto, G., Galimberti, A., De Mattia, F., Labra, M. and Bruno, A., 2020. Tasting the differences: microbiota analysis of different insect-based novel food. Food Research International 137: 109426.

Garofalo, C., Milanović, V., Cardinali, F., Aquilanti, L., Clementi, F. and Osimani, A., 2019. Current knowledge on the microbiota of edible insects intended for human consumption: a state-of-theart review. Food Research International 125: 108527. https://doi. org/10.1016/j.foodres.2019.108527

Greenhalgh, J.P. and Amund, D., 2019. Examining the presence of Cronobacter spp. in ready-to-eat edible insects. Food Safety 7: 7478. https://doi.org/10.14252/foodsafetyfscj.d-19-00004.

Holah, J.T., 2014. Cleaning and disinfection practices in food processing. In: Lelieveld, H.L.M., Holah, J.T. and Napper, D. (eds.) Hygiene in food processing: principles and practice, $2^{\text {nd }}$ edition. Woodhead Publishing, Philadelphia, PA, USA, 304 pp.

Holt, P.S., Geden, C.J., Moore, R.W. and Gast, R.K., 2007. Isolation of Salmonella enterica serovar enteritidis from houseflies (Musca domestica) found in rooms containing Salmonella serovar enteritidis-challenged hens. Applied and Environmental Microbiology 73: 6030-6035. https://doi.org/10.1128/AEM.00803-07

Houben, D., Daoulas, G., Faucon, M.-P. and Dulaurent, A.-M., 2020. Potential use of mealworm frass as a fertilizer: impact on crop growth and soil properties. Nature Scientific Reports 10: 4659. https://doi.org/10.1038/s41598-020-61765-x

International Platform of Insects for Food and Feed (IPIFF), 2019a. IPIFF Contribution Paper on the application of insect frass as fertilising product in agriculture. $6 \mathrm{pp}$. Available at https://ipiff. org/wp-content/uploads/2019/09/19-09-2019-IPIFF-contributionon-insect-frass-application-as-fertilising-product-final-version.pdf International Platform of Insects for Food and Feed (IPIFF), 2019b. IPIFF guide on good hygiene practices for European Union producers of insects as food and feed. IPIFF, Brussels, Belgium, 108 pp. Available at: https://ipiff.org/wp-content/uploads/2019/12/ IPIFF-Guide-on-Good-Hygiene-Practices.pdf

International Platform of Insects for Food and Feed (IPIFF), 2020. Factsheet: Edible insects on the European market. Retrieved from https://ipiff.org/wp-content/uploads/2020/06/10-06-2020-IPIFFedible-insects-market-factsheet.pdf
Jacxsens, L., Kussaga, J., Luning, P.A., Van der Spiegel, M., Devlieghere, F. and Uyttendaele, M., 2009. A microbial assessment scheme to measure microbial performance of food safety management systems. International Journal of Food Microbiology 134: 113-125. https:// doi.org/10.1016/j.ijfoodmicro.2009.02.018

Jay, J., Loessner, M. and Golden, D., 2005. Modern food microbiology. Springer, Boston, MA, US, 790 pp. https://doi.org/10.1007/b100840

Jeßberger, N., Krey, V.M., Rademacher, C., Böhm, M.-E., Mohr, A.-K., Ehling-Schulz, M., Scherer, S. and Märtlbauer, E., 2015. From genome to toxicity: a combinatory approach highlights the complexity of enterotoxin production in Bacillus cereus. Frontiers in Microbiology 6: 560. https://doi.org/10.3389/fmicb.2015.00560

Jiang, C.-L., Jin, W.-Z., Tao, X.-H., Zhang, Q., Zhu, J., Feng, S.-Y., Xu, X.-H., Li, H.-Y., Wang, Z.-H. and Zhang, Z.-J., 2019. Black soldier fly larvae (Hermetia illucens) strengthen the metabolic function of food waste biodegradation by gut microbiome. Microbial Biotechnology 12: 528-543. https://doi.org/10.1111/1751-7915.13393

Kamau Njage, P., Sawe, C., Onyango, C., Habib, I., Njeru Njagi, E., Aerts, M. and Molenberghs, G., 2017. Microbiological performance of food safety control and assurance activities in a fresh produce processing sector measured using a microbiological scheme and statistical modeling. Journal of Food Protection 80: 177-188. https:// doi.org/10.4315/0362-028X.JFP-16-233

Kashiri, M., Marin, C., Garzón, R., Rosell, C.M., Rodrigo, D. and Martínez, A., 2018. Use of high hydrostatic pressure to inactivate natural contaminating microorganisms and inoculated E. coli O157:H7 on Hermetia illucens larvae. PLoS ONE 13: e0194477. https://doi.org/10.1371/journal.pone.0194477

Klammsteiner, T., Walter, A., Bogataj, T., Heussler, C.D., Stres, B., Steiner, F.M., Schlick-Steiner, F.M., Arthofer, W. and Insam, H., 2020. The core gut microbiome of black soldier fly (Hermetia illucens) larvae raised on low-bioburden diets. Frontiers in Microbiology 11: 993. https://doi.org/10.3389/fmicb.2020.00993

Kooh, P., Ververis, E., Tesson, V., Boué, G. and Federighi, M., 2019. Entomophagy and public health: a review of microbiological hazards. Health 11: 1272-1290. https://doi.org/10.4236/health.2019.1110098

Kort, R., O’Brien, A.C., Van Stokkum, I.H.M., Oomes, S.J.C.M., Crielaard, W., Hellingwerf, K.J. and Brul, S., 2005. Assessment of heat resistance of bacterial spores from food product isolates by fluorescence monitoring of dipicolinic acid release. Applied and Environmental Microbiology 71: 3556-3564. https://doi.org/10.1128/ AEM.71.7.3556-3564.2005

Lalander, C.H., Diener, S., Magri, M.E., Zurbrügg, C., Lindström, A. and Vinnerås, B., 2013. Faecal sludge management with the larvae of the black soldier fly (Hermetia illucens) - from a hygiene aspect. Science of the Total Environment 458-460: 312-318. https://doi. org/10.1016/j.scitotenv.2013.04.033

Lalander, C.H., Fidjeland, J., Diener, S., Eriksson, S. and Vinnerås, B., 2015. High waste-to-biomass conversion and efficient Salmonella spp. reduction using black soldier fly for waste recycling. Agronomy for Sustainable Development 35: 261-271. https://doi.org/10.1007/ s13593-014-0235-4

Liu, Q., Tomberlin, J.K., Brady, J.A., Sanford, M.R. and Yu, Z., 2008. Black soldier fly (Diptera: Stratiomyidae) larvae reduce Escherichia coli in dairy manure. Environmental Entomology 37: 1525-1530. https://doi.org/10.1603/0046-225x-37.6.1525 
Man, C.M.D and Jones, A., 2000. Shelf life evaluation of foods, $2^{\text {nd }}$ edition. Aspen Publishers, Gaithersburg, MD, USA, 292 pp.

Mancini, S., Fratini, F., Tuccinardi, T., Turchi, B., Nuvoloni, R. and Paci, G., 2019a. Effects of different blanching treatments on microbiological profile and quality of the mealworm (Tenebrio molitor). Journal of Insects as Food and Feed 5: 225-234. https:// doi.org/10.3920/JIFF2018.0034

Mancini, S., Fratini, F., Turchi, B., Mattioli, S., Dal Bosco, A., Tuccinardi, T., Nozic, S. and Paci, G., 2019b. Former foodstuff products in Tenebrio molitor rearing: effects on growth, chemical composition, microbiological load, and antioxidant status. Animals 9: 484. https:// doi.org/10.3390/ani9080484

Mancini, S., Paci, G., Ciardelli, V., Turchi, B., Pedonese, F. and Fratini, F., 2019c. Listeria monocytogenes contamination of Tenebrio molitor larvae rearing substrate: preliminary evaluations. Food Microbiology 83: 104-108. https://doi.org/10.1016/j.fm.2019.05.006

Martin, T.C., Visconti, A., Spector, T.D. and Falchi, M., 2018. Conducting metagenomic studies in microbiology and clinical research. Applied Microbiology and Biotechnology 102: 8629-8646. https://doi.org/10.1007/s00253-018-9209-9

Martins, S.B., Häsler, B. and Rushton, J., 2014. Economic aspects of zoonoses: impact of zoonoses on the food industry. In: Sing, A. (ed.) Zoonoses - infections affecting humans and animals: focus on public health aspects. Springer, Dordrecht, the Netherlands, 1137 pp.

Müller, A., Wiedmer, S. and Kurth, M., 2019. Risk evaluation of passive transmission of animal parasites by feeding of black soldier fly (Hermetia illucens) larvae and prepupae. Journal of Food Protection 82: 948-954. https://doi.org/10.4315/0362-028X.JFP-18-484

Murefu, T.R., Macheka, L., Musundire, R. and Manditsera, F.A., 2019. Safety of wild harvested and reared edible insects: a review. Food Control 101: 209-224. https://doi.org/10.1016/j. foodcont.2019.03.003

Osés, S.M., Luning, P.A., Jacxsens, L., Santillana, S., Jaime, I. and Rovira, J., 2012. Microbial performance of food safety management systems implemented in the lamb production chain. Journal of Food Protection 75: 95-103. https://doi.org/10.4315/0362-028X. JFP-11-263

Rosef, O. and Kapperud, G., 1983. House flies (Musca domestica) as possible vectors of Campylobacter fetus subsp. jejuni. Applied and Environmental Microbiology 45: 381-383. https://doi.org/10.1128/ aem.45.2.381-383.1983

Rosnes, J.T., Skåra, T. and Skipnes, D., 2011. Recent advances in minimal heat processing of fish: effects on microbiological activity and safety. Food and Bioprocess Technology 4: 833-848. https:// doi.org/10.1007/s11947-011-0517-7

SciCom, 2018. Advies 23-2018 van het Wetenschappelijk Comité van 21 december 2018. Inschatting van het risico voor de consument van Bacillus cereus in levensmiddelen. Wetenschappelijk Comité van het Federaal Agentschap voor de Veiligheid van de Voedselketen. Available at: http://www.afsca.be/wetenschappelijkcomite/ adviezen/2018/_documents/Advies23-2018_SciCom2018-04_B. cereus.pdf

Shelomi, M., 2020. Potential of black soldier fly production for pacific small island developing states. Animals 10: 1038. https://doi:10.3390/ ani10061038
Shelomi, M., Wu, M.-K., Chen, S.-M., Huang, J.-J. and Burke, C.G., 2020. Microbes associated with black soldier fly (Diptera: Stratiomyidae) degradation of food waste. Environmental Entomology 49: 405-411. https://doi.org/10.1093/ee/nvz164

Swinscoe, I., Oliver, D.M., Ørnsrud, R. and Quilliam, R.S., 2020. The microbial safety of seaweed as a feed component for black soldier fly (Hermetia illucens) larvae. Food Microbiology 91: 103535. https:// doi.org/10.1016/j.fm.2020.103535

Tong Thi, A.N., Jacxsens, L., Noseda, B., Samapundo, S., Nguyen, B.L., Heyndrickx, M. and Devlieghere, F., 2014. Evaluation of the microbiological safety and quality of Vietnamese Pangasius hypophthalmus during processing by a microbial assessment scheme in combination with a self-assessment questionnaire. Fisheries Science 80: 1117-1128. https://doi.org/10.1007/s12562-014-0786-y

Uman L.S., 2011. Systematic reviews and meta-analyses. Journal of the Canadian Academy of Child and Adolescent Psychiatry 20: 57-59.

Van Cauteren, D., Le Strat, Y., Sommen, C., Bruyand, M., Tourdjman, M., Jourdan-Da Silva, N., Couturier, E., Fournet, N., De Valk, H. and Desenclos, J.-C., 2017. Estimated annual numbers of foodborne pathogen-associated illnesses, hospitalizations, and deaths, France, 2008-2013. Emerging Infectious Diseases 23: 1486-1492. https:// doi.org/10.3201/eid2309.170081

Vandeweyer, D., Crauwels, S., Lievens, B. and Van Campenhout, L., 2017. Microbial counts of mealworm larvae (Tenebrio molitor) and crickets (Acheta domesticus and Gryllodes sigillatus) from different rearing companies and different production batches. International Journal of Food Microbiology 242: 13-18. https://doi.org/10.1016/j. ijfoodmicro.2016.11.007

Vandeweyer, D., Lievens, B. and Van Campenhout, L., 2020a. Identification of bacterial endospores and targeted detection of foodborne viruses in industrially reared insects for food. Nature Food 1: 511-516. https://doi.org/10.1038/s43016-020-0120-z

Vandeweyer, D., Lievens, B. and Van Campenhout, L., 2020b. Microbiological safety of industrially reared insects for food: identification of bacterial endospores and targeted detection of foodborne viruses. BioRxiv. https://doi.org/10.1101/2020.04.22.055236

Vandeweyer, D., Wynants, E., Crauwels, S., Verreth, C., Viaene, N., Claes, J., Lievens, B. and Van Campenhout, L., 2018. Microbial dynamics during industrial rearing, processing, and storage of tropical house crickets (Gryllodes sigillatus) for human consumption. Applied and Environmental Microbiology 84: e00255-18. https:// doi.org/10.1128/AEM.00255-18

Varotto Boccazzi, I., Ottoboni, M., Martin, E., Comandatore, F., Vallone, L., Spranghers, T., Eeckhout, M., Mereghetti, V., Pinotti, L. and Epis, S., 2017. A survey of the mycobiota associated with larvae of the black soldier fly (Hermetia illucens) reared for feed production. PLoS ONE 12: e0182533. https://doi.org/10.1371/ journal.pone.0182533

Wang, Y.-S. and Shelomi, M., 2017. Review of black soldier fly (Hermetia illucens) as animal feed and human food. Foods 6: 91. https://doi.org/10.3390/foods6100091

World Health Organization, 1995. Application of risk analysis to food standards issues. Report of the Joint FAO/WHO Expert Consultation. FAO, Rome, Italy. Available at: http://www.fao.org/3/ ae922e/ae922e00.htm\#Contents 
Wu, N., Wang, X., Xu, X., Cai, R. and Xie, S., 2020. Effects of heavy metals on the bioaccumulation, excretion and gut microbiome of black soldier fly larvae (Hermetia illucens). Ecotoxicology and Environmental Safety 192: 110323. https://doi.org/10.1016/j. ecoenv.2020.110323

Wynants, E., Frooninckx, L., Crauwels, S., Verreth, C., De Smet, J., Sandrock, C., Wohlfahrt, J., Van Schelt, J., Depraetere, S., Lievens, B., Van Miert, S., Claes, J. and Van Campenhout, L., 2018. Assessing the microbiota of black Soldier fly larvae (Hermetia illucens) reared on organic waste streams on four different locations at laboratory and large scale. Microbial Ecology 77: 913-930. https://doi.org/10.1007/ s00248-018-1286-x

Wynants, E., Frooninckx, L., Van Miert, S., Geeraerd, A., Claes, J. and Van Campenhout, L., 2019. Risks related to the presence of Salmonella sp. during rearing of mealworms (Tenebrio molitor) for food or feed: survival in the substrate and transmission to the larvae. Food Control 100: 227-234. https://doi.org/10.1016/j. foodcont.2019.01.026

Wynants, E., Crauwels, S., Lievens, B., Luca, S., Claes, J., Borremans, A., Bruyninckx, L. and Van Campenhout, L., 2017. Effect of postharvest starvation and rinsing on the microbial numbers and the bacterial community composition of mealworm larvae (Tenebrio molitor). Innovative Food Science and Emerging Technologies 42: 8-15. https://doi.org/10.1016/j.ifset.2017.06.004

Xu, H.S., Roberts, N., Singleton, F.L., Attwell, R.W., Grimes, D.J. and Colwell, R.R., 1982. Survival and viability of nonculturable Escherichia coli and Vibrio cholerae in the estuarine and marine environment. Microbial Ecology 8: 313-323. https://doi.org/10.1007/ BF02010671
Yu, G., Cheng, P., Chen, Y., Li, Y., Yang, Z., Chen, Y. and Tomberlin, J.K., 2011. Inoculating poultry manure with companion bacteria influences growth and development of black soldier fly (Diptera: Stratiomyidae) larvae. Environmental Entomology 40: 30-35. https:// doi.org/10.1603/EN10126

Zhan, S., Fang, G., Cai, M., Kou, Z., Xu, J., Cao, Y., Bai, L., Zhang, Y., Jiang, Y., Luo, X., Xu, J., Xu, X., Zheng, L., Yu, Z., Yang, H., Zhang, Z., Wang, S., Tomberlin, J.K., Zhang, J. and Huang, Y., 2020. Genomic landscape and genetic manipulation of the black soldier fly Hermetia illucens, a natural waste recycler. Cell Research 30: 50-60. https:// doi.org/10.1038/s41422-019-0252-6

Zhao, X., Zhong, J., Wei, C., Lin, C.-W. and Ding, T., 2017. Current perspectives on viable but non-culturable state in foodborne pathogens. Frontiers in Microbiology 8: 580. https://doi.org/10.3389/ fmicb.2017.00580

Zheng, L., Crippen, T., Holmes, L., Singh, B., Pimsler, M.L., Benbow, M.E., Tarone, A.M., Dowd, S., Yu, Z., Vanlaerhoven, S.L., Wood, T.K. and Tomberlin, J.K., 2013. Bacteria mediate oviposition by the black soldier fly, Hermetia illucens (L.), (Diptera: Stratiomyidae). Nature Scientific Reports 3: 2563. https://doi.org/10.1038/srep02563

Zwietering, M.H., Straver, J.M. and Van Asselt, E.D., 2016. The range of microbial risks in food processing. In: Lelieveld, H., Holah, J. and Gabric, D. (eds.) Handbook of hygiene control in the food industry, $2^{\text {nd }}$ edition. Woodhead Publishing, Duxford, UK, pp. 43-54. https:// doi.org/10.1016/B978-0-08-100155-4.00004-2 